\title{
An Analysis of the Impact on the Performance of Work Safety and Health Workers (Case Study: Construction One Galaxy) Surabaya Project
}

\author{
Khrisna Putra Sasmana \\ Narotama University, Surabaya \\ khrisnaps@gmail.com
}

\begin{abstract}
Number of work accident in the world is still high .In indonesia total of accident case caused by work years 2011- 2014 the highest in 2013 namely 35.917. The purpose of this research to know the influence of safety and health work of the performance of workers the "One Galaxy Surabaya" project. This research including research quantitative, by using kuisioner a gatherer data, sample used is 100 employees "One The Galaxy Surabaya" project, analysis data using test simple linear regression. Based on 6 spss test, obtained the results of the of the respondents, valid responses it is reliable, scattered normal, data does not happen multikolinierity, does not happen heteroskedastys and there is the influence of between health and occupational safety and. employee performance. There is the influence of health and safety work $(\mathrm{X})$ against employee performance $(\mathrm{Y})$ it is proven with the value of the importance of 0,004 smaller than the probability of 0,05 and known the value of $r$ square 0,662 . as much as This value containing the sense that the influence of health and safety work $(\mathrm{X})$ on performance employees $(\mathrm{Y})$ reached $66,2 \%$ while $33,8 \%$ the performance of employees affected by other variables that are not researched health and safety work (K3) have been implemented in an optimal so as to improve the performance of a construction worker"One Galaxy Surabaya" project
\end{abstract}

Keywords : safety and health work,employee performance

\section{INTRODUCTION}

In indonesia cases of an accident caused by work years 2011- 2014 most high on 2013 namely 35.917 work accident. caseMeanwhile data from an accident caused by work every day is going on around 6.000 fatal, work accident in the world with the number of accidents caused by work recorded by year end 2015 105.182, cases as many as and the case heavy accident resulting in death recorded 2.375 cases of the total number of accidents, work summed up the total amount of work accidents every year rise to $5 \%-10 \%$. Ilo, ( 2016 ).

Work safety and health ( k3 ) very important applied in the company, especially in company that moves in the services sector construction that employees feel secure, comfortable, and healthy in doing activities jobs and company can have optimal results from the performance of employees .To ensure work safety and health ( k3 ) some company that moves in the services sector construction have used ohsas 18001: 2007 as a prerequisite smk3 in a company. Ohsas was required by of safety management system and kesehata ( $\mathrm{k} 3$ ), that organization can control risks $\mathrm{k} 3$ and improve its performance according to sayuti ( 2013: 196 have occupational health is easy for the possibility of threats against health someone who works on something place or company during the time work normal. Sense for another that is, the health employment is health both physical and spiritual .

PT Nusantara Tatamulia indah is one of the moving company in the construction industry.Some work when it was handled under the auspices of pt nusantara tatamulia beautiful among them are one signature surabaya, gallery one east to residences, spazio tower 2, spazio office, the factory tong ji, formosa batam, the church mawarsharon surabaya, elyon school, ciputra world surabaya phase 3, danone galaxy surabaya.The project one galaxy surabaya is a mega project in which there are various types of building, namely the mall the hotel, office and apartment.A construction project involves many workers more or less have the number of workers 1000 . peopleThe project one galaxy surabaya have a target for 
completion within a period of 5-6 years dating from september 2015 up until november 2020. Based on the obsevasi a pitch that has been doing, it is happened a few work accident either in the form of light and heavy

Work accident experienced workers 32 scene of an accident within last 10 months, the number of accidents work light 25 cases and the number of accidents keja weigh as much as 7 cases. The process of construction building construction one the galaxy is one of the projects involving many people in the process of construction and needed a good performance from all parties so that required management right moment in dealing with problems as $\mathrm{k} 3$ to achieve the target of construction and objectives .Of the thing that has been in explain above so did a study analysis influence work safety and health of the performance of workers construction project one the galaxy surabaya.

On the other hand the fact the formulation of a problem that made on the basis of background of the above analysis of the rear over as follows:

1. Whether the occupational health and safety had a significant effect on the performance of project workers one business meeting the galaxy surabaya?

2. How to minimize the employment accident or an incident that undesirable in this country in its development one business meeting the galaxy surabaya?

For giving easy services and smooth running of of discussion to be addressed in this research reverence he was very they are also required to there was a limit of a problem . The unclear division of a problem that was provided they are:

1. An object assessment research is a company pt tatamulia provided by the private sector nusantantara beautiful as undisciplined flirtatious and alluring contractor development project but should be one business meeting the galaxy surabaya

2. The data in use represents data for that is in get on our spread of the questionnaire was for the adults working the project and the objective of the interview directly depend on the particular workers to invest in a project .

3. Respondents and research data obtained from 100 workers who are involved in the construction of surabaya one galaxy .

4. Level respondents at this research is foreman to construction workers.

5. Respondents in research is extracted from permanent workers have project dabbling in this world for approximately five years.

6. Data to be researched in this study is the data on quantity

and the purpose of writing is to:

1.Know how big the influence of work safety and health workers project on performance surabaya one galaxy

2.Know how to minimize accidents or incidents in development unwanted surabaya one galaxy .

\section{MATERIALS AND METHODS}

The research is conducted by research methodology quantitative. descriptiveThe purpose of this research, which is described a number of variables that with regard to the problem and a unit in particular between the phenomenon that tested.In this research techniques used to collect data, research namely by the questionnaire as instrument to answer a set of questions or a written statement to the location of survey respondents were in the projects one galaxy surabaya with the research began in december 13 201812 2019. until january

In the implementation of, survey need some data and equipment that can support processing and the preparation of, namely the required data sheets, questionnaires stationery and cameras to emerge from the collection of data collection activities this is the primary and secondary data. dataThe primary data includes the results of an answer of the respondents employees one galaxy surabaya, project while secondary data covering a data project and a profile of respondents data collection techniques on the research was conducted using a questionnaire or the survey. The questionnaire is a list of statements or questions sent to the respondents either directly or indirectly ( by mail or a middleman ) to obtain the required information ( hermawan and amirullah, 2016)

Was used in the study quantitative research, of bond issuance will be a method of the solution of a problem a planned and of paying close attention, with evil designs a structured tight, the collection of data in an unsystematic manner staying well under control and were loyal to the preparation of the theory that which is inferred it should also be noted inductive within the framework of proof in the form of a 
hypothesis in an empirical manner .( sugiyono , 2011: 7 ). The method of analysis the fit and proper test data using quality data, it is anticipated that analysis linear regression simple

\section{RESULTS}

Public records respondents intended to identify respondents identity.Respondents in extract in this research.Each respondents had of identity data from sex, age, education and long work.For more details, table shows researchers set out below

Tabel 1.

Respondent Description

\begin{tabular}{|c|c|c|}
\hline Category & $\mathbf{N}$ & $\%$ \\
\hline \multicolumn{3}{|l|}{ Sex } \\
\hline Laki-laki & 100 & $100 \%$ \\
\hline Perempuan & 0 & $0 \%$ \\
\hline \multicolumn{3}{|l|}{ Age } \\
\hline $20-29 \mathrm{Th}$ & 41 & $41 \%$ \\
\hline $30-39 \mathrm{Th}$ & 30 & $30 \%$ \\
\hline$>40 \mathrm{Th}$ & 29 & $29 \%$ \\
\hline \multicolumn{3}{|l|}{ Education } \\
\hline SMP & 14 & $14 \%$ \\
\hline SMA / sederajat & 82 & $82 \%$ \\
\hline S-1 & 4 & $4 \%$ \\
\hline \multicolumn{3}{|l|}{ Work Duration } \\
\hline $1-5$ years & 65 & 65 \\
\hline $6-10$ years & 24 & 24 \\
\hline$>11$ years & 11 & 16 \\
\hline
\end{tabular}

From the table above can be seen that respondents men as many as 100 people, with the equal to $100 \%$.When no some respondents are sex women. This indicates that all respondents male sex ( $100 \%)$ .Respondents between the ages of 20 - 29 years as many as 41 people ( $41 \%$ ), respondents aged 30 - 39 as many as 30 people ( $30 \%$ ). And aged over 40 years twenty-nine ( $29 \%$ ). Respondents with the education level respondents with a junior high school education the 14 ( $14 \%$ ), high school as many as 82 people ( $82 \%$ and an undergraduate degree as many as four people ( $4 \%$ ), .Can be concluded that the majority of respondents with the education level high school ( $82 \%$ ). Respondents with the education level respondents with long work 5-1 years 65 people ( $65 \%$ ) of respondents by working 6-10 of the 24 ( $24 \%$ ) and most of 11 years as many as 11 people ( $16 \%)$, .Can be concluded that half respondents with the education level high school ( $50 \%$ )

to analyze data be used, qualitative analysis tools which is a method that aims to clarify the testimony of the facts and the research results and the means the quantitative analysis, namely drngan evaluating data on the research and used as a basis of proof the permasalhan.dalam this research tool used to analyze the results of research is to use simple linear regression analysis 
Table 2

Simple Linier Regression Test

\begin{tabular}{|l|l|l|l|}
\hline \multicolumn{3}{|c|}{ Variables Entered/Removed $^{\mathrm{b}}$} \\
\hline \multirow{4}{*}{ Model } & Variables & Variables & \\
& Entered & Removed & Method \\
\hline 1 & K3 $^{\text {a }}$ & & Enter \\
\hline
\end{tabular}

a. All requested variables entered.

b. Dependent Variable: Kinerja Karyawan

Model Summary

\begin{tabular}{|l|r|r|r|c|}
\hline Model & $\mathrm{R}$ & R Square & \multicolumn{1}{|c|}{$\begin{array}{c}\text { Adjusted R } \\
\text { Square }\end{array}$} & $\begin{array}{c}\text { Std. Error of the } \\
\text { Estimate }\end{array}$ \\
\hline 1 & $.0814^{\mathrm{a}}$ & .662 & .628 & 1.40171 \\
\hline
\end{tabular}

a. Predictors: (Constant), kinerja karyawan

ANOVA $^{b}$

\begin{tabular}{|ll|r|r|r|r|r|}
\hline Model & & Sum of Squares & df & Mean Square & F & Sig. \\
\hline 1 & Regression & 38.353 & 1 & 38.353 & 19.521 & $.001^{\mathrm{a}}$ \\
& Residual & 19.649 & 46 & 1.966 & & \\
& Total & 58.000 & 47 & & & \\
\hline
\end{tabular}

a. Predictors: (Constant), K3

b. Dependent Variable: kinerja karyawan

\begin{tabular}{|c|c|c|c|c|c|c|}
\hline \multicolumn{7}{|c|}{ Coefficients $^{\mathrm{a}}$} \\
\hline \multirow{2}{*}{\multicolumn{2}{|c|}{ Model }} & \multicolumn{2}{|c|}{ Unstandardized Coefficients } & $\begin{array}{l}\text { Standardized } \\
\text { Coefficients }\end{array}$ & \multirow[b]{2}{*}{$\mathrm{t}$} & \multirow[b]{2}{*}{ Sig. } \\
\hline & & B & Std. Error & Beta & & \\
\hline 1 & (Constant) & 35.422 & 1.616 & & 13.083 & .000 \\
\hline & $\mathrm{K} 3$ & .550 & .117 & -.814 & -4.410 & .004 \\
\hline
\end{tabular}

a. Dependent Variable: kinerja karyawan

In general the regression equation is linear simple is $\mathrm{Y}=\mathrm{a}+\mathrm{bX}$

While to know the value of the regression coefficient is can aim for an output that are on table coefficients. A number of coefficients = constant unstandardized.In table on the value of 35,422.

This figure is the constant who had the sense that if there is no health and safety ( $\mathrm{x}$ ) work but it went consistent employee performance ( $y$ ) 35 , is as much as 422

$\mathrm{b}=$ numbers the regression coefficient.It is worth as much as 0,550.This figure means that every additional $1 \%$ level of health and safety work ( $\mathrm{x}$ ) then employee performance $(\mathrm{y})$ will 0,550 . increased byTest the hypothesis serves to find out if the regression coefficient is significant. or not

$\mathrm{H} 0$ : there is not an influence health and safety work $(\mathrm{x})$ on employe performance $(\mathrm{y})$

$\mathrm{H} 1$ : there the influence of health and safety work $(\mathrm{x})$ on employe performance $(\mathrm{y})$

Based on output on the table known significance ( sig. 0,004) from the probability of smaller 0,05 , so it can be concluded that $\mathrm{h} 1 \mathrm{~h} 0$ received and accepted that any impact health and safety work ( $\mathrm{x}$ ) to employee performance ( $\mathrm{Y}$ )

To know the influence health and safety work $(\mathrm{x})$ to the employee performance ( $\mathrm{Y}$ ) in regression analysis simple, linear can based in the $r$ square or $r 2$ output spss contained in the model rangkuman below . 
Model Summary

\begin{tabular}{|l|c|r|r|c|}
\hline Model & $\mathrm{R}$ & R Square & \multicolumn{1}{|c|}{$\begin{array}{c}\text { Adjusted R } \\
\text { Square }\end{array}$} & $\begin{array}{c}\text { Std. Error of the } \\
\text { Estimate }\end{array}$ \\
\hline 1 & $.0814^{\mathrm{a}}$ & .662 & .628 & 1.40171 \\
\hline
\end{tabular}

a. Predictors: (Constant), kinerja karyawan

\section{DISCUSSION}

Of the output the results of above known value of $0,662 \mathrm{r}$ square. This value means that the impact of occupational health and safety ( $\mathrm{x}$ ) of the performance of employees ( $\mathrm{y}$ ) is of 66,2\% and 33,8 $\%$ performance employees influenced by variables other aren t pursuing

Research credit is in line with it permanasari ( 2014 ) with a title it is anticipated that analysis the influence of occupational health and safety ( $\mathrm{k} 3$ ) tehadap the performance of with gratification of teaching experience as variables reaches as high as no intervening ( her study for a tens of thousands of workers part production of pt .Counting a herbal medicine a fountain palur, karanganyar, central java ) who have deduced is that there the influence of work safety all companies these pay rises on performance tens of thousands of workers .

The occupational health and safety ( k3 ) is an effort of or the thought of any as well as of the implications that has been showed in order to ensure the wholeness and in this world of good of the flesh as well as spiritual labor especially in and human beings in general, the handiwork of and culture , in order to improve welfare on the workforce for individuals ( kuswana in eggy aufal marom and bambang swasto sunuharyo , 2014: 22 ) .

By applying occupational health and safety program ( k3 ) create security and comfort for employees in working, will encourage employees to work more productive. Research in line with this who done son and prasetya ( 2018 ) said the occupational health and safety program ( or to ) significant employee performance.Research in line is the son of the 2018 ( ) that concludes that work safety and health affects $\mathrm{k} 3$ ( ) employee performance.This outcome will also supported by research conducted by 2018 ( fatoni ) that concludes variable labor safety and variable occupational health have leverage simultaneously on variables employee performance.

The author opinion that the performance of employees affected by health and safety work because the company is trying to increase awareness of employees work, covering knowledge understanding standard operating procedures ( sop ), job the use of the occupational safety and comfort and security in this upaya-upaya worked so as to minimize the accident rate. employees workBased on observations and sampling in the field can be seen that there are some of the efforts made by corporations to minimize work accident on the project of one galaxy surabaya is:

1. Put up warning sign in every place that is an area prone to the accidents both light and heavy. The installation of rambu-rambu this warning is one of a preventive manner at once a call to obey the rules $\mathrm{k} 3$ to support workers. own performanceThis is because of safety and occupational health impact on employee performance.

2. Having safety morning for the workers and the staff routinely ( 1 weeks once ).Safety morning is apples are routinely every morning it will be done before the implementation of the activity of the project of.Safety morning of development projects one galaxy surabaya followed by all the workers and the staff all the projects one galaxy surabaya.The performance of employees who are high enough then factors of safety and health work of great interest to minimise accidents were an employee with, knowledge work work understanding standard operating procedures ( sop )

3. Between workers from each other and the when he.Sop in effect in company will not run if not followed awareness to the individuals.

4. Give punishment clearly and staff to workers who violates sop k3.punishment is a last resort done by the company to solicitation and a formerly given not show the.Sanction given by a company to workers in the form of fine rp 500.000; for all types of violations and are valid for all workers without except.While the sanction applicable to staff the company the offense given sp3 for employees and contract dinaikan salary for 1 in for permanent workers. 


\section{CONCLUSION}

Based on the analysis of the data, the following conclusions: obtained

1. Based on the spss 6 , obtained the data respondents valid responses, it is reliable, data are normal , there will be no multikolinieritas, there will be no heteroskedastisitas and is the between health and occupational safety and employee performance .

2. How to minimize employment accident or unwanted incident in one galaxy surabaya covering knowledge development work, understanding standart operating procedures ( sop ) work, the use of a occupational safety and comfort and security place this upaya-upaya worked so as to minimize the number of accident employees work

Based on the analysis and discussion, data hence writers can recommend a few things as follows:

1. For the company /, project is expected to always uphold the health and safety of the workers for supporting the project and project terselesainya one galaxy surabaya, by giving the appeal, the soup and evaluation on the efforts the $\mathrm{k} 3$

2. For the researchers next, for the improvement of research results, so can be added other variables like the influence of compensation to employee performance on the rise

\section{REFERENCES}

Eggy Aufal Marom Bambang Swasto Sunuharyo (2014) Pengaruh Keselamatan Dan Kesehatan Kerja (K3) Terhadap Kinerja Karyawan (Studi pada Karyawan bagian Produksi Perusahaan PT Lion Metal Works Tbk)

Gunawan dan Waluyo. 2015. Risk Based Behavioral Safety Membangun Kebersamaan Untuk Mewujudkan Keunggulan Operasi. Jakarta: PT Gramedia Pustaka Utama

Hermawan, S dan Amirullah. 2016. Metode Penelitian Bisnis Pendekatan Kuantitaif dan Kualitatif. Malang: Media Nusa Creative, Cetakan Pertama.

International Labour Organization (ILO). 2016. Hari Keselamatan dan Kesehatan seDunia: Mencegah kecelakaan Kerja melalui pelaksanaan manajemen risiko K3.. www.ilo.org diakses pada 8 Februari 2019

Permanasari, Johana. 2014.Analisis Pengaruh Kesehatan dan Keselamatan Kerja (K3) Tehadap Kinerja Dengan Kepuasan Kerja Sebagai Variabel Intervening (Studi pada Karyawan Bagian Produksi PT. Jamu Air Mancur Palur, Karanganyar, Jawa Tengah). Jurnal Fakultas Ekonomika dan Bisnis Universitas Diponegoro

Sanjaya, Muhammad Taufiek Rio. 2015. Pengaruh Disiplin Kerja Dan Motivasi Kerja Terhadap Kinerja Karyawan Pada Hotel Ros In Yogyakarta, Universitas Negeri Yogyakarta, Yogyakarta.

Sayuti, Abdul Jalaludin. 2013. Manajemen Kantor Praktis. Bandung: Alfabeta

Sobirin, Mohamad. 2016. Kinerja Proyek Konstruksi Bangunan Gedung Di Pengaruhi Oleh Beberapa Faktor Seperti Sumber Daya Manusia, Sumber Daya Alat Dan Sumber Daya Material. Universitas Tama Jagakarsa. Jakarta Selatan.

Sugiyono. 2011. Metode Penelitian Kuantitatif, Kualitatif dan R\&D. Bandung: Afabeta

Undang-undang tentang Keselamatan dan Kesehatan Kerja No. 1 tahun 1970

Widodo, S. E. (2015). Manajemen Pengembangan Sumber Daya Manusia, Yogyakarta: Pusaka Pelajar. 